\title{
PENGARUH PENGGUNAAN MEDIA GAMBAR BERSERI TERHADAP KEMAMPUAN MENULIS TEKS PROSEDUR SISWA KELAS VII SMP SULTAN ISKANDAR MUDA TAHUN PELAJARAN 2018/2019
}

\author{
Alicia Indriyanto ${ }^{1}$, Hilman Haidir ${ }^{2}$, Annisa $^{3}$ \\ Universitas Prima Indonesia ${ }^{1}$, Universitas Prima Indonesia ${ }^{2}$, Universitas Prima Indonesia ${ }^{3}$ \\ Pos-el: aliciaindriyanto@gmail.com ${ }^{1}$, hilman_haidir_3212@yahoo.co.id ${ }^{2}$, \\ rindi.nisa48@gmail.com ${ }^{3}$
}

\begin{abstract}
ABSTRAK
Penelitian ini merupakan penelitian kuantitatif. Metode penelitian ini menggunakan metode eksperimen dengan desain penelitian Two Group Posttest Design. Populasi penelitian ini adalah siswa kelas VII SMP Sultan Iskandar Muda. Penentuan sampel dilakukan dengan teknik simple random sampling. Berdasarkan teknik tersebut maka diperoleh kelas VII B sebagai kelas eksperimen dan kelas VII D sebagai kelas kontrol. Teknik pengumpulan data pada penelitian ini adalah tes tertulis, yaitu posttest. Proses pengumpulan data dengan cara menugaskan siswa untuk menulis teks prosedur. Sebelum dilakukan analisis data, terlebih dahulu melakukan uji normalitas dan uji homogenitas yang menunjukkan bahwa skor posttest berdistribusi normal dan homogen. Teknik analisis data yang digunakan adalah uji-t. Hasil analisis data menunjukkan bahwa adanya perbedaan keterampilan menulisteks prosedur siswa kelas VII SMP Sultan Iskandar Muda dengan menggunakan media gambar berseri dan tanpa menggunakan media gambar berseri. Setelah dianalisis dengan menggunakan rumus uji-t yang dilakukan dengan manual, maka terlihat dari tabel t pada taraf $\alpha=0,05$ dengan $\mathrm{dk}=82-2=80$ nilai thit > ttab $(27,61>2,00)$ maka dapat dibuktikan bahwa media gambar berseri memiliki pengaruh yang lebih tinggi dibandingkan dengan metode kovensional terhadap kemampuan menulis.
\end{abstract}

Kata Kunci: Media Gambar Berseri, Menulis, Teks Prosedur.

\begin{abstract}
This research is quantitative research. This research method uses an experimental method with two group posttest design research design. The population of this study was the seventh grade students of Sultan Iskandar Muda Middle School. Determination of the sample is done by simple random sampling technique. Based on the technique, it was obtained class VII B as the experimental class and class VII D as the control class. The data collection technique in this study was a written test, namely posttest. The process of collecting data by assigning students to write procedure texts. Before data analysis, the normality test and homogeneity test first showed that the posttest score was normally distributed and homogeneous. The data analysis technique used is the t-test. The results of data analysis showed that there was a difference in the procedure of writing skills in seventh grade students of Sultan Iskandar Muda Middle School using serial images and without the use of radiant media. After being analyzed using the t-test formula which is done manually, it can be seen from table $t$ at the level of $\alpha=$ 0.05 with $d k=82-2=80$ values of thit $>t t a b(27.61>2.00)$ then it can be proved that serial image media has a higher effect than the conventional method of writing ability.
\end{abstract}

Keywords: Serial Image Media, Writing, Procedure Text. 


\section{PENDAHULUAN}

Indonesia merupakan negara yang kaya akan budaya. Budaya tersebutpun tersebar diberbagai penjuru daerah di Indonesia. Budaya yang terdapat dalam satu daerah akan berbeda dengan budaya daerah lainnya, termasuk kuliner atau makanan khas dari masingmasing daerah. Masyarakat Indonesia dituntut untuk dapat melestarikan budayanya.Peserta didik dapat melestarikan budaya Indonesia dengan memilih tema sesuai keinginannya yang bersangkutan dengan budaya yang terdapat di Indonesia. Oleh karena itu, peserta didik tidak melupakan budaya yang beragam yang terdapat di Indonesia. Salah satu upaya untuk dapat melestarikan budaya Indonesia melalui mata pelajaran bahasa Indonesia adalah dengan membuat teks prosedur.

Dalam hal ini teks prosedur lebih ditujukan untuk siswa jenjang Sekolah Menengah Pertama. Teks prosedur merupakan teks yang berisi langkahlangkah atau tahapan-tahapan yang telah ditentukan yang harus ditempuh untuk mencapai tujuan yang maksimal.

Siswa dapat melakukan langkahlangkah tersebut dengan bantuan guru untuk menempuh tujuan tertentu. Melalui teks prosedur, banyak orang lebih mudah untuk memahami suatu cara atau mempraktikkan sesuatu. Hal ini disebabkan karena langkah-langkah dalam teks prosedur ditulis secara berurutan.

Selain itu, peserta didik juga dapat memahami cara penulisan kalimat efektif yang baik dan benar melalui teks prosedur. Penulisan kalimat sesuai dengan ejaan yang disempurnakan (EYD). Materi teks prosedur merupakan salah satu teks yang sesuai dengan kurikulum 2013 yang berlaku.

Proses pembelajaran harus menyentuh tiga ranah, yaitu sikap, pengetahuan dan keterampilan. Pembelajaran pada kurikulum 2013 untuk semua jenjang dilaksanakan pada pendekatan ilmiah. Pembelajaran pada kurikulum 2013 menggunakan pembelajaran yang nyata dan menekankan keterlibatan peserta didik dalam proses belajar secara aktif sehingga peserta didik terlatih untuk dapat menemukan sendiri berbagai pengetahuan yang dipelajari.

Di samping itu, perkembangan ilmu pengetahuan dan teknologi semakin mendorong para guru untuk semakin variatif dalam menggunakan media pembelajaran. Kegiatan belajarmengajar dan media yang digunakan tersebut merupakan alat-alat yang sesuai dengan perkembangan zaman. Media tidak dapat dipisahkan dengan kegiatan belajar-mengajar. Penggunaan media juga berpengaruh positif atas hasil belajar peserta didik.

Kemampuan mayoritas dari peserta didik kelas VII SMP Sultan Iskandar Muda masih rendah. Peserta didik masih belum paham mengenai penulisan teks prosedur yang baik dan benar. Hal itu disebabkan oleh kurangnya minat dan antusiasbelajar peserta didik. Banyak dari peserta didik secara tidak sadar telah menganggap bahwa mata pelajaran Bahasa Indonesia itu membosankan.

Faktor tersebut dikarenakan guru kurang mampu dalam membuat suasana belajar menjadi menyenangkan. Selain itu, guru kurang mampu membangkitkan motivasi dan memfokuskan perhatian peserta didik untuk dapat berpartisipasi aktif dalam proses pembelajaran. Hal tersebut menjadi alasan bahwa minat belajar siswa dalam pelajaran Bahasa Indonesia kurang.

Berdasarkan latar belakang tersebut, maka masalah dalam penelitian ini yakni: Bagaimanakah kemampuan menulis teks prosedur siswa dengan menggunakan media gambar berseri pada siswa kelas VII SMP Sultan Iskandar Muda, Bagaimanakah kemampuan menulis tek prosedur siswa tanpa menggunakan media gambar 
berseri pada siswa kelas VII SMP Sultan Iskandar Muda, Apakah terdapat pengaruh yang siginifikan dalam penggunaan media gambar berseri dengan kemampuan menulis teks prosedur pada siswa kelas VII SMP Sultan Iskandar Muda. Sehingga tujuan dalam penelitian ini adalah untuk mengetahui pengaruh penggunaan media gambar berseri yang signifikan terhadap kemampuan menulis teks prosedur siswa kelas VII SMP Sultan Iskandar Muda.

\section{METODE PENELITIAN}

Jenis penelitian ini merupakan eksperimen. Penelitian ini menggunakan pendekatan kuantitatif. Sugiyono (2013 : 7) mengatakatan pendekatan penelitian kuantitatif ialah metode penelitian yang berlandasan pada filsafat posivisme, digunakan untuk meneliti pada populasi atau sampel tertentu, pengumpulan data menggunakan instrument penelitian, analisis data bersifat kuantitatif/statistic, dengan tujuan untuk menguji hipotesis yang telah ditetapkan. Penelitian menggunakan pendekatan kuantitatif karena semua data yang berkumpul disusun dalam bentuk angka-angka yang selanjutnya dianalisis untuk mendapatkan suatu data.

Menurut Arikunto (2010:12)" desain atau rancangan penelitian dapat dikatakan alur pengumpulan data eksperimen pembelajaran yang dilaksanakan di dalam kelas berdasarkan jenis penelitiannya." Oleh sebab itu, eksperimen penelitian ini menggunakan desain two group postest design only. Desain ini memberikan perlakuan setelah dilakukan penentuan kelompok kontrol dan kelompok eksperimen. Selanjutnya, dilakukan pengukuran terhadap variabel terikat pada kedua kelompok tersebut.

\section{HASIL DAN PEMBAHASAN}

Kemampuan menulis teks prosedur siswa kelas VII SMP Sultan Iskandar Muda tanpa menggunakan media gambar berseri adalah sebagai berikut: tidak ada siswa dengan kategori sangat baik dengan rentang nilai $85-100$, sebanyak 6 siswa atau 14,63\% kategori baik dengan rentang nilai $75-84$, sebanyak 14 siswa atau 34,15\% kategori cukup dengan rentang nilai $65-74$, sebanyak 18 siswa atau 43,90\% kategori kurang dengan rentang nilai 55 - 64, dan sebanyak 3 siswa atau 7,32\% kategori sangat kurang dengan rentang nilai 0 54.

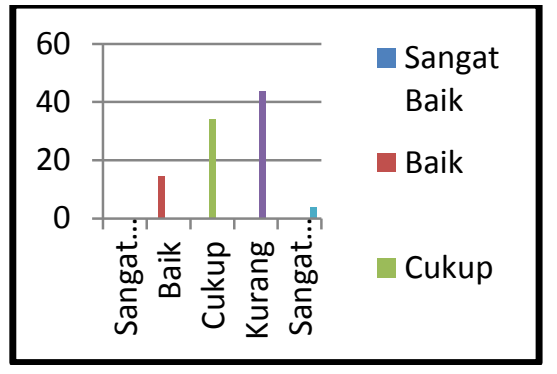

\section{a. Kemampun Menulis Teks Prosedur Siswa Kelas Eksperimen}

Kemampuan menulis teks prosedur siswa kelas VII SMP Sultan Iskandar Muda dengan menggunakan media gambar berseri adalah sebagai berikut: sebanyak 9 siswa atau 21,95\% kategori sangat baik dengan rentang nilai 85 100 , sebanyak 20 siswa atau $48,78 \%$ kategori baik dengan rentang nilai 75 84, sebanyak 11 siswa atau 26,83\% kategori cukup dengan rentang nilai 65 74 , sebanyak 1 siswa atau $2,44 \%$ kategori kurang dan tidak adanya siswa dengan kategori sangat kurang.

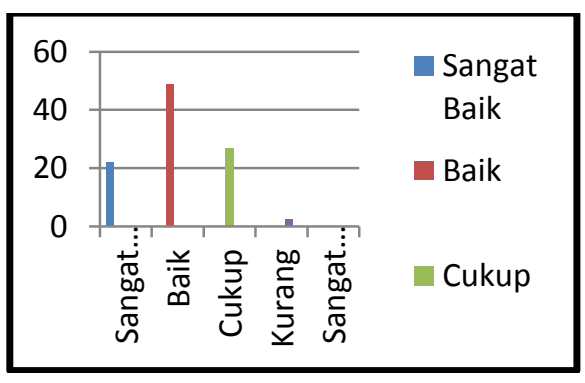

\section{b. Kemampun Menulis Teks} Prosedur Siswa Kelas Eksperimen

Kemampuan menulis teks prosedur siswa kelas VII SMP Sultan Iskandar 
Muda dengan menggunakan media gambar berseri adalah sebagai berikut: sebanyak 9 siswa atau 21,95\% kategori sangat baik dengan rentang nilai 85 100 , sebanyak 20 siswa atau $48,78 \%$ kategori baik dengan rentang nilai 75 84 , sebanyak 11 siswa atau $26,83 \%$ kategori cukup dengan rentang nilai 65 74, sebanyak 1 siswa atau 2,44\% kategori kurang dan tidak adanya siswa dengan kategori sangat kurang.

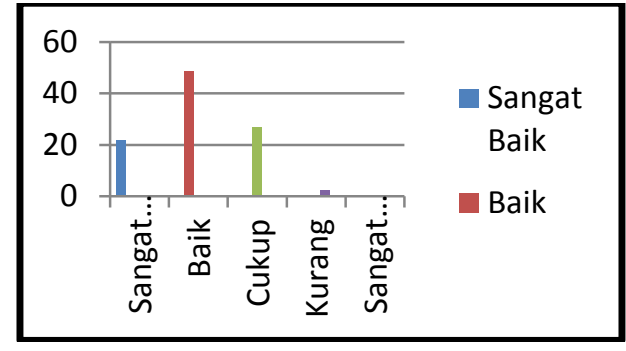

Pembahasan pada penelitian ini didasarkan pada data perolehan nilai kelas kontrol dan kelas eksperimen. Data tersebut dari hasil posstest yang dijadikan bahan bagi peneliti untuk mendeskripsikan sekaligus menjawab tiga poin rumusan masalah.

Pertama, hasil posstest menunjukkan kemampuan menulis teks prosedur tanpa menggunakan media gambar berseri pada kelas kontrol berada dalam kategori kurang atau belum memuaskan. Pada kelas kontrol diketahui nilai minimum yaitu 54 dan perolehan nilai maksimum yaitu 79 dengan nilai rata-rata 64,80.

Kedua, hasil posttest menunjukkan kemampuan menulis teks prosedur dengan menggunakan media pembelajaran gambar berseri berada dalam kategori baik atau memuaskan. Hal tersebut dapat dilihat dari perolehan nilai minimum yaitu 63 dan perolehan nilai maksimum yaitu 88 dengan nilai rata-rata 78,5.

Ketiga, keefektifan penggunaan media pembelajaran gambar berseri dapat dilihat dari uji hipotesis dan langkah yang peneliti lakukan terlebih dahulu adalah uji normalitas dan uji hmogenitas pada kedua kelas. Hasil uji normalitas pada kelas kontrol yang diperoleh yaitu $\mathrm{L}_{\text {hit }}<\mathrm{L}_{\text {tab }}(0,937<0,138)$ dan pada kelas eksperimen diperoleh $\mathrm{L}_{\text {hit }}$ $<\mathrm{L}_{\text {tab }}(0,9778<0,138)$ atau dengan kata lain kedua kelas berada pada kategori normal. Sedangkan hasil uji homogenitas pada kelas kontrol dan kelas eksperimen dengan taraf signifikan $\alpha=0,05$ dan dk pembilang 40 serta $\mathrm{dk}$ penyebut 40 atau $\left(\mathrm{F}_{0,05(40,40)}\right)$ yaitu $\mathrm{F}_{\mathrm{tab}}(0,92<2,11)$. Dengan kata lain kedua kelas berada dalam kategori sama (homogen).

Kelas kontrol dan kelas eksperimen berada dalam kategori normal dan homogen maka uji hipotesis dapat dilakukan. Hasil uji hipotesis menunjukkan nilai $t_{\text {hit }}>t_{\text {tab }}(27,61>$ 2,00) atau dengan kata lain $\mathrm{H}_{\mathrm{a}}$ diterima atau penggunaan media pembelajaran gambar berseri terbukti efektif diterapkan dalam pembelajaran menulis teks prosedur siswa kelas VII SMP Sultan Iskandar Muda

\section{SIMPULAN}

Setelah dianalis dan diolah data penelitian dan pembahasan, disimpulkan tiga hal berikut ini: Pertama, kemampuan menulis teks prosedur pada siswa kelas VII SMP Sultan Iskandar Muda Tahun Pelajaran 2018/2019 tanpa menggunakan media gambar berseri di kategorikan kurang dalam menulis teks prosedur. Hal ini dibuktikan dari nilai rata-rata kelas 64,80 dengan nilai maksimum 79 dan nilai minimum 54 . Kedua, Kemampuan menulis teks prosedur pada siswa kelas VII SMP Sultan Iskandar Muda Tahun Pelajaran 2018/2019 dengan menggunakan media gambar berseri dikategorikan baik dalam menulis teks prosedur.

Hal ini dibuktikan dengan nilai rata-rata 78,5 dengan nilai maksimum 88 dan nilai minimum 63. Ketiga, Menulis teks prosedur dalam media pembelajaran gambar berseri sangat berpengaruh dalam meningkatkan kemampuan menulis teks prosedur. Hal 
ini dapat dilihat pada uji " $t$ " diketahui thit > ttab $(27,61>2,00)$ sehingga dalam penelitian ini $\mathrm{H} 0$ ditolak dan $\mathrm{Ha}$ diterima. Jadi dapat disimpulkan bahwa kemampuan menulis teks prosedur yang diajarkan dengan menggunakan media gambar berseri berpengaruh lebih baik dibandingkan kemampuan menulis teks prosedur yang diajarkan dengan metode konvensional.

Berdasarkan kesimpulan tersebut, peneliti menyarankan hal sebagai berikut: Pertama, untuk guru Bahasa Indonesia dapat dijadikan sebagai salah satu cara untuk meningkatkan kemampuan dan hasil belajar dalam proses pembelajaran. Kedua, untuk siswa, diharapkan melalui media gambar berseri dapat meningkatkan kemampuan menulis teks prosedur.

\section{DAFTAR PUSTAKA}

Arsyad, Azhar. 2015. Media Pembelajaran Edisi Revisi. Jakarta: PT Raja Grafindo Persada

Kosasih, E. 2014. Jenis-jenis Teks dalam Mata Pelajaran Bahasa Indonesia Mahasiswa dan Umum. Bandung: Yrama Widya

Mahsun. 2014. Teks dalam Pembelajaran Bahasa Indonesia Kurikulum 2013. Jakarta: PT RajaGrafindo Persada

Wati, Ega Rima. 2016. Ragam Media

Pembelajaran. Jakarta: Kota Pena. 